\title{
Cikkismertetés: Új pszichoaktív szerek: kihívások a monitorozás, a szabályozás és a népegészségügyi válaszlépések területén
}

\author{
Article review: New psychoactive substances: Challenges for drug \\ surveillance, control, and public health responses
}

Ismertető: $\quad$ Péterfi Anna $\square$ Tarján Anna, Horváth Gergely Csaba

Emberi Erőforrások Minisztériuma, Nemzeti Drog Fókuszpont

Ismertetett cikk: Peacock A, Bruno R, Gisev N, Degenhardt L, Hall W, Sedefov R, White S, Thomas KV, Farrell M, Griffiths P. New psychoactive substances: challenges for drug surveillance, control, and public health responses. Lancet. 2019; 394: 1668-84.

doi: $\underline{10.1016 / 50140-6736(19) 32231-7}$

Beküldve: $\quad$ 2019.12.31.

doi: $\quad$ 10.24365/ef.v61i1.554

Kulcsszavak: új pszichoaktív szerek; kábítószerek; Európa; kezelés; szabályozás

Keywords: new psychoactive substances; drugs; Europe; treatment; regulation

A The Lancet folyóirat droghasználattal foglalkozó cikksorozatának (Series - Drug Use) 4. közleményében jelent meg az új pszichoaktív szerekkel (ÚPSZ; new psychoactive substances, NPS) kapcsolatos kihívásokat tárgyaló írás. A sorozat eddigi cikkeiben az opiátfogyasztás globális mintázatairól, a kannabisz orvosi és rekreációs használatának népegészségügyi következményeiről, valamint a stimulánshasználatra adott válaszlépésekről olvashattunk ${ }^{1,2,3}$. Jelen cikk a 2000-es évektől kezdődően felbukkanó új pszichoaktív szerekre adott monitorozási, szabályozási és népegészségügyi válaszlépések mentén próbálja megrajzolni, mennyiben alkalmasak a meglévő rendszereink és eszközeink arra, hogy a jövőben megjelenő új jelenségekre, anyagokra adekvát választ nyújtsunk.

A cikk négy témakörre bontja a tárgyalni kívánt témákat. Elsőként az új ÚPSZ-ekkel kapcsolatos definíciós kihívásokat mutatja be. Az új pszichoaktív szerek, mint összesítő megnevezés mellett számos alternatív címkével illették a pszichoaktív szerek e csoportját az elmúlt közel két évtized alatt (többek között: designer drogok'). De mit is értünk pontosan új pszichoaktív szerek alatt? A különböző szakterületek (pl. szabályozás, kutatók, terepen dolgozók) különböző szempontok szerint definiálják a jelenséget. Ami közös a definíciókban, hogy alapvetően olyan vegyületekre vonatkoznak, melyek a 2000-es évek közepén kezdtek felbukkanni, s melyeket valamilyen módon elkülöníthetünk a már régóta ismert kábítószerektől és pszichotróp anyagoktól. Ez az elhatárolás azonban nem magától értetődő. A definíció szempontjából kulcsfontosságú, hogy monitorozási, szabályozási vagy szakpolitikai szempontok érvényesülnek-e a meghatározás során. Emellett a másik lényeges tényező az időbeliség. Egyrészt

¡További angol nyelvű elnevezések: legal highs, research chemicals, substances sold for the purpose of scientific research 
ezeket a szereket jellemzően újdonságuk miatt különítjük el a klasszikusabb szerektől, másrészt a definíciók egy része a szabályozás szempontjából fogja meg a jelenséget, mely időben változó, így nem teremt időben állandó kategóriákat. A szerzők végül meghatározzák saját definíciójukat, melyet a The Lancet Drug Use sorozatában egységesen alkalmaznak. E szerint az ÚPSZ-ek olyan bódító vagy pszichotróp szerek, melyek a 2000-es évek elejétől kezdődően váltak elérhetővé, vagy terjedt el fogyasztásuk pszichoaktív tulajdonságaik miatt. Az ÚPSZ-ek nem szerepelnek a kábítószereket és pszichotróp anyagokat szabályozó nemzetközi egyezmények jegyzékein, vagy csak 2015 után kerültek fel azokra, ugyanakkor hasonló népegészségügyi kockázatot jelenthetnek, mint a jegyzéken lévő anyagok; ezen felül meghatározásuk a szintetikus anyagokra fókuszál, a növényi alapú szerek kizárásával. A definíció meghatározását követően a szerzők a jelenség okainak és jellemzőinek leírásával folytatják. Megállapításuk szerint az ÚPSZ-jelenség egyértelmúen új fejezet a kábítószerek evolúciójában. Ennek meghatározói a tudományos és gyógyszerszabadalmi irodalom erőteljes kiaknázása új vegyületek azonosítása érdekében, illetve a globalizáció, az internet és az információs technológiáknak köszönhetően bekövetkezett gyors változások a kínálat és kereslet alakulásában. Az ÚPSZ-ek gyártása jellemzően gyenge szabályozási mechanizmusokkal rendelkező fejlődő országokban történik (bár a szerzők nem nevezik meg ezeket, de a szakirodalom szerint elsősorban Kínáról és Indiáról van szó), míg a végső produktum előállítása (pl. tablettázás) és csomagolás már sokszor a célországban zajlik. Az ÚPSZ-ek előállításából, viszonylag egyszerú, és alacsony kockázattal történő mozgatásából és a célpiacon való szabályozatlanságából eredően új kereskedői csoportok - kezdetben akár valós üzletekkel és nyilvánosan hozzáférhető (clear weben lévő) online boltokkal rendelkező vállalkozók kapcsolódtak be a kereskedelembe. Az új technológiák nem csupán az ÚPSZ-ek nagy- és kiskereskedelmét könnyítették meg, hanem a fogyasztásukkal kapcsolatos információkhoz való hozzájutást is.

Az ÚPSZ-jelenség egyik meghatározó jellemzője és folyamatos változékonyságának mozgatója a szabá- lyozási környezet. Az új szerek előretörését az elsősorban egyedi listás megoldásraii építő nemzetközi, illetve azon alapuló nemzeti szabályozási rendszerek képtelenek voltak kezelni. Az évek előrehaladtával azonban a legtöbb fejlett ország kialakított valamilyen átmeneti, vagy hosszabb távú szabályozási megoldást, mellyel az egyezményeken alapuló egyedi listás rendszernél proaktívabban voltak képesek reagálni, az országukban felbukkanó újabb és újabb anyagokra. A szabályozási megoldások tárgyalása kapcsán a szerzők potenciális veszélyként emelik ki, hogy az ÚPSZ-ek kereskedelme várhatóan a hatékonyabb szabályozással rendelkező fejlettebb országokból a szabályozással nem rendelkező fejlődő országokba helyeződik át a jövőben. Az ÚPSZ-ek elmúlt 15 évre visszatekintő történetének kulcseseményeit bemutató ábra átláthatóan mutatja be az új anyagok megjelenésének dinamikáját, a szabályozással kapcsolatos jelentősebb változásokat, a kereskedelmet alakító fontosabb eseményeket, valamint a szakirodalom által tárgyalt jelentősebb mérgezéseket, haláleseteket.

A szerzők által tárgyalt második témakör az ÚPSZhasználat mögött álló, szakirodalom által azonosított motivációk. A használókkal készített kérdőíves vizsgálatok szerint alapvetően a klasszikus kábítószerekhez hasonló indokok vezettek az új szerek használatához is: azok terápiás, funkcionális és élvezeti hatásai. Kezdetben e szerek népszerűségét növelte legális (vagy legalábbis szabályozatlan) státuszuk, mivel az a biztonságosság (hamis) érzetét keltette a használókban, valamint a szerhasználat nem járt jogi következményekkel. Mindezek mellett a hozzáférhetőség, az ár, illetve a rutin drogtesztek általi kimutathatatlanságuk meghatározó tényezők az ÚPSZ-ek választásában.

Harmadik témakörként az ÚPSZ-ek hozzáférhetőségéről és használatuk elterjedtségéről, valamint e szerek használatával összefüggő ártalmakról adnak hosszabb összegzést. A hozzáférhetőség kapcsán a szerzők elsősorban az újonnan azonosított szerek számának időbeni változására koncentrálnak. Kiemelt keretben ad áttekintést a cikk az ÚPSZ-ek megjelenésével és elterjedtségével kapcsolatos lehetséges módszerekről, azokat a megbízhatóság (laboranalitikai bizonyíték megléte) szerint rendsze-

\footnotetext{
ii Ez azt jelenti, hogy meghatározott vegyületek szerepelnek a jogszabályok jegyzékein, így az azoktól csak kismértékben is eltérő kémiai szerkezetű vegyületek már nem esnek a szabályozás hatókörébe.
} 
rezve. Az elterjedtség meghatározására elsősorban a nagy, véletlenmintás populációs vizsgálatokra támaszkodnak, melyek kapcsán azonban rengeteg korlátba ütköznek a szerzők a módszertani különbségek miatt. Ezek közül az egyik legjelentősebb az ÚPSZ-ek eltérő meghatározása, illetve e vizsgálatok limitált képessége a marginalizált - és jellemzően az ÚPSZ tekintetében legérintettebb - társadalmi csoportok leírására. Összegezve az irodalmi áttekintés alapján begyűjtött vizsgálati eredményeket arra jutnak, hogy az egyes országok eltérő mértékben érintettek, de általában alacsonyabb az ÚPSZ-használat a klasszikus szerek használatához viszonyítva, melyet megerősítenek a szentinel csoportokban (speciális, pl. egy adott weboldal látogatói körében) végzett vizsgálatok is. Az azonosított szakirodalom szerint a fejlett országokban jellemző, hogy az ÚPSZhasználat nem önmagában álló probléma, hanem egy polidrog-mintázat része.

A szerzők az ÚPSZ-használat ártalmaival kapcsolatos szakirodalomi áttekintés során elsősorban olyan cikkeket azonosítottak, melyek egyes esetekről vagy eset-sorozatokról adtak leíró összegzést. Ezek alapján elmondható, hogy az ÚPSZ-ek egyes csoportjainál a fogyasztás jellemzően hasonló ártalmakkal jár együtt, mint azon szerek esetében, melynek hatásait leginkább utánozza az adott ÚPSZ-csoport (pl. új stimulánsok - klasszikus stimulánsok). Ezek alól a szintetikus kannabinoidok jelentik a kivételt, melyek ártalmai - az áttekintett cikkek tükrében eltérőek, és súlyosabbak, mint a kannabisz esetében. Ezen felül természetesen nagyobb kockázatot jelent ezen anyagok fogyasztása a fogyasztott hatóanyagokkal kapcsolatos ismerethiány miatt, mivel a változó összetétel és hatóanyag-tartalom miatt a biztonságos adagolás nehezen meghatározható.

Az írás negyedik témaköreként a válaszlépéseket tekintik át, beleértve ezen anyagok monitorozását, szabályozását, valamint a klinikai és népegészségügyi válaszlépéseket. A monitorozás szempontjából statikus, inkább reaktív, mint proaktív rendszerek nem voltak képesek megfelelő képet adni a dinamikusan változó ÚPSZ-jelenségrôl. Ezen új anyagok monitorozása egy más surveillance modellt igényelt a nemzetközi szervezetektől és helyi szinten egyaránt. Azok tekinthetők sikeres monitorozási modelleknek, melyek a rutin adatgyüjtések mellett innovatívabb, proaktívabb módszerekre (pl. fogyasztói anyagbevizsgálás, szennyvízvizsgálat), továbbá a formális források mellett az informális forrásokra is (például média-megjelenések elemzése) építenek, illetve ezek eredményeit a rutin adatokkal együtt, a háromszögelés módszerével (triangulálva) használják fel. Az új modellek logikája, hogy nemcsak naprakészen, hanem proaktívan keresik és azonosítják a jelzéseket a különböző adatforrásokban, melyek időben előrejelzik a piacon megjelenő szerekkel kapcsolatos lehetséges népegészségügyi kockázatokat.

A szabályozást vizsgálva a szerzők arra jutnak, hogy az ÚPSZ-ek megjelenése erőpróba elé állította az Egyesült Nemzetek Szervezete (ENSZ) nemzetközi egyezményeken nyugvó szabályozását. Az ENSZ szabályozó testülete 2014-ben vizsgált először ÚPSZ-t, ami majd egy évtized az első megjelenések észleléséhez képest. Az ezt követő években az ENSZ több tucat ÚPSZ-t helyezett jegyzékre és ezáltal nemzetközi szabályozás alá. A szerzők ezzel kapcsolatban több kritikai megjegyzést is tesznek. Úgy vélik, problematikus nagy számban vegyületeket nemzetközi szabályozás alá helyezni, mert az negatív hatással lehet a kutatásokra, és ezen anyagok legitim használatára; számos tagállam felkészületlen technikailag ilyen mennyiségú új anyag azonosítására; illetve a listára vétel olyan mértékben köti le az ENSZ drogügyi döntéshozó testületének (Commission on Narcotic Drugs, CND) kapacitásait, hogy az a nemzetközi drogprobléma egyéb területeire is kihathat. Az országos és regionális kábítószer-szabályozási megoldásokról is rövid áttekintést adnak a szerzők. Helyi szinten is - különösen az új szerek megjelenését megelőzően - elsősorban a már említett egyedi listás szabályozás volt az elterjedt. Ezt a típusú szabályozást az ÚPSZ-ek előállításában és kereskedelmében érdekelt szereplők ügyesen kijátszva újabb és újabb vegyületeket dobtak piacra, melyet a szabályozás nem volt képes követni. Néhány ország - válaszként a jelenségre olyan szabályozási technikákat kezdett alkalmazni, melyek a vegyületek szélesebb csoportjainak szabályozását tették lehetővé. Ilyenek az analóg, a generikus és a neurokémiai szabályozási módszerek. Emellett voltak országok, akik általános tilalmat (blanket ban) vezettek be a pszichoaktív szerekre. Voltak próbálkozások olyan szabályozásra is, melyek a megjelenő szerek piacának keretek közé szorítását igyekeztek elérni, nem annak tiltását - a legismertebb ezek közül az új-zélandi szabályozás. Ezen szabályozások azzal a céllal születtek, hogy csökkentsék a szerhasználókat sújtó stigmatizációt és 
bűnügyi szankciókat. Helyi szinten tehát rugalmasabb válaszok születtek a jelenségre, mint nemzetközi szinten.

Az ÚPSZ-fogyasztás akut ártalmai kapcsán alkalmazható klinikai válaszlépések szempontjából problémát jelent, hogy a szerhasználó által ismeretlen a fogyasztott anyag, és azt a rapid tesztek sem képesek kimutatni. Az új pszichoaktív szerekkel kapcsolatos problémák kezelésével foglalkozó, brit NEPTUNE útmutató ezért a tüneti alapon történő beavatkozásokat javasolja, az egyéb támogató beavatkozások kíséretében. Az akut ártalmakhoz képest még kisebb a nemzetközi szakirodalomban azonosítható információ az ÚPSZ használat krónikus ártalmairól. A szintetikus kannabinoidok esetében a függőség gyorsabb kialakulásáról, és a kannabisznál komplexebb elvonási tünetekről számol be a szakirodalom. A függőség és elvonási tünetek kockázata néhány új típusú stimuláns esetében is azonosítható volt. Ezen problémák esetében a klinikai útmutatók azon bizonyíték-alapú beavatkozásokat javasolják alkalmazni, mint a klasszikus szerek esetében - a lépcsőzetes ellátás elvére alapozva - az igényekre reagáló legmegfelelőbb szint megválasztásával, az alacsonyabb intenzitású beavatkozásoktól kezdve az elvonási tünetek kezelésén át a bentlakásos ellátási formákig.

\section{TANULSÁGOK A HAZAI SZAKEMBEREK SZÁMÁRA}

Záró gondolataikban a szerzők előrejelzéseket fogalmaznak meg a pszichoaktív szerek jelenségének jövőbeni alakulására vonatkozóan. Kockázatként azonosítják, hogy egyre potensebb szerek kerülnek majd a nemzetközi piacra. Az eddigi, elsősorban a fejlett országokat érintő ÚPSZ-jelenség egyre inkább átterjed azon fejlődő országokra, ahol nagy a fiatalkorúak aránya, továbbá jellemző a gyors társadalmi átrendeződés, a szegénység, a marginalizáció és a kormányzati probléma. Azonban ezekben az országokban a bekövetkező változások kezdetben nem lesznek azonosíthatók a monitorozó rendszerek megfelelő kapacitásának hiányában. Úgy látják, hogy az internet a jövőben is meghatározó platformja lesz az új szerek gyors terjedésének a világban, mely további kihívásokat jelent a monitorozás és szabályozás szempontjából. A jövő kérdései között említik, hogy vajon elérkezik-e egy fiatal generáció, akiket elsősorban az ÚPSZ használat jellemez majd, és mindez hogyan alakítja az egyéb szerhasználati szokásaikat, és az őket érő ártalmakat.

Az ÚPSZ-ek megjelenése és elterjedése megmutatta, hogy eredménytelen a válaszlépések specifikus szertípushoz történő igazítása, mivel a szerek és a szerhasználati mintázatok folyamatosan és dinamikusan változnak a kínálat és egyéb preferenciák mentén. A cikk szerzői úgy látják, hogy a jövő válaszlépéseinek a szerhasználat egészségügyi és szociális ártalmai által érintett emberekre kell fókuszálniuk, melyek kialakításába elengedhetetlen az ő bevonásuk is.

Az írás jól felépített, a kiemelés különböző eszközeivel átláthatóan és követhetően tagolja, és teszi láthatóvá a kulcsüzeneteket. Összegző ábrái és szövegdobozai hasznos kiindulópontot jelenthetnek a témát tárgyaló későbbi értekezéseknek, tananyagoknak. Kritikaként talán az fogalmazható meg, hogy az új anyagok azonosítása és száma túl nagy hangsúlyt kap az anyagban, míg az elterjedtség egyéb mutatói, melyek a következmények meghatározása szempontjából sokkal meghatározóbbak, háttérbe szorulnak. Az ártalmakkal kapcsolatos összefoglaló túlságosan is a szintetikus kannabinoidokra koncentrál, elhanyagolva az egyéb ÚPSZ-csoportokat, és csupán érintőlegesen tér ki az utóbbi években jelentős problémát okozó szintetikus opiátok okozta mérgezésekre és halálesetekre (melyeket utóbb, a válaszlépésekkel foglalkozó részben említenek). 


\section{HIVATKOZÁSOK}

\footnotetext{
${ }^{1}$ Degenhardt L, Grebely J, Stone J, et al. Global patterns of opioid use and dependence: harms to populations, interventions, and future action. Lancet. 2019;394(10208):1560-1579. doi: 10.1016/S0140-6736(19)32229-9

${ }^{2}$ Hall W, Stjepanović D, Caulkins J et al. Public health implications of legalising the production and sale of cannabis for medicinal and recreational use. Lancet. 2019; 394(10208):1580-1590. doi: 10.1016/50140-6736(19)31789-1 ${ }^{3}$ Farrell M, Martin NK, Stockings E et al. Responding to global stimulant use: challenges and opportunities. Lancet. 2019; 394(10209):1652-1667. doi: 10.1016/S0140-6736(19)32230-5
} 